\title{
Offsite Radiological Consequence Calculation for the Bounding Mixing of Incompatible Materials Accident
}

\section{K. R. Sandgren}

CH2M HILL Hanford Group, Inc.

Richland, WA 99352

U.S. Department of Energy Contract DE-AC27-99RL14047

$\begin{array}{lll}\text { EDT/ECN: } & 723851 & \text { UC: N/A } \\ \text { Cost Center: } 7 \text { G530 } & \text { Charge Code: } 502644 \\ \text { B\&R Code: } & \text { N/A } & \text { Total Pages: } 42\end{array}$

Key Words: Incompatible materials, sulfuric acid, carbon dioxide, DST, double-shell tank, SST, single-shell tank, bulk chemical addition, bounding, offsite, accident, radiological, consequence

Abstract: This document quantifies the offsite radiological consequence of the bounding mixing of incompatible materials accident for comparison with the 25 rem Evaluation Guideline established in Appendix A of DOE-STD-3009. The bounding accident is an inadvertent addition of acid to a waste tank. The calculated offsite dose does not challenge the Evaluation Guideline. Revision 4 updates the analysis to consider bulk chemical additions to SSTs.

TRADEMARK DISCLAIMER. Reference herein to any specific commercial product, process, or service by trade name, trademark, manufacturer, or otherwise, does not necessarily constitute or imply its endorsement, recommendation, or favoring by the United States Government or any agency thereof or its contractors or subcontractors.

Printed in the United States of America. To obtain copies of this document, contact: Document Control Services, P.O. Box 950, Mailstop H6-08, Richland WA 99352, Phone (509) 372-2420; Fax (509) 376-4989.

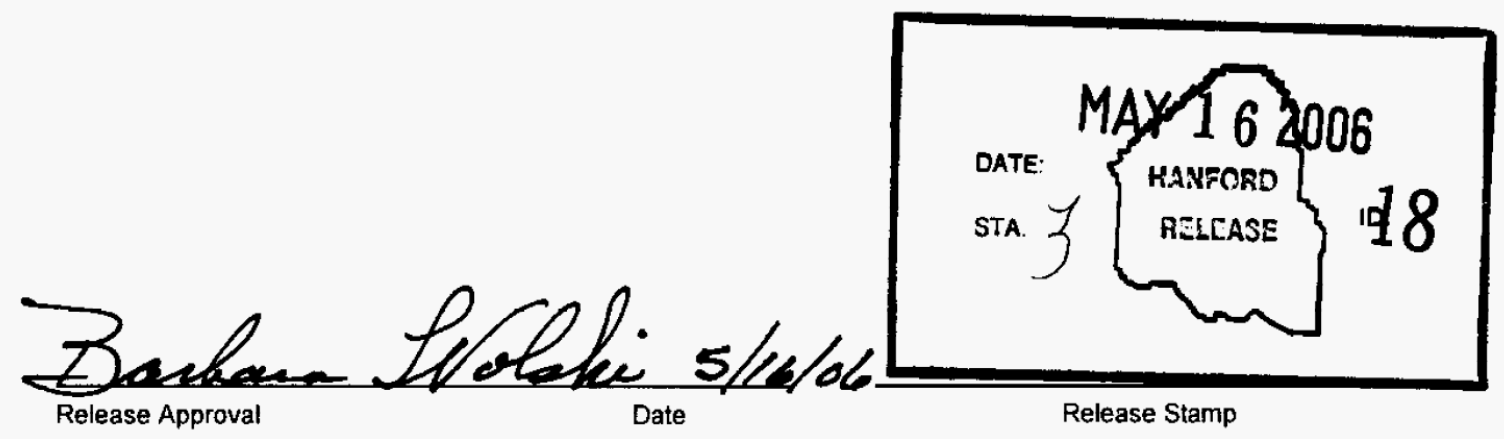

Approved For Public Release 


\section{RPP-9689 REV 4}

\section{CONTENTS}

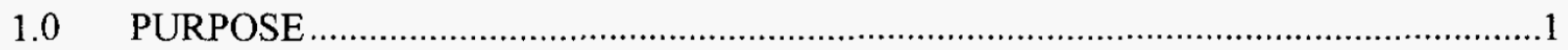

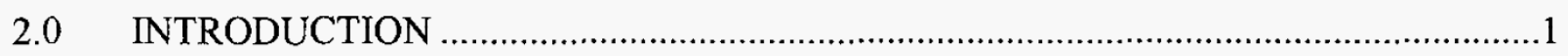

3.0 OFFSITE RADIOLOGICAL CONSEQUENCES ....................................................

3.1 CONTRIBUTION OF AEROSOLIZED WASTE …..........................................

3.2 CONTRIBUTION OF THE HIGH-EFFICIENCY PARTICULATE AIR

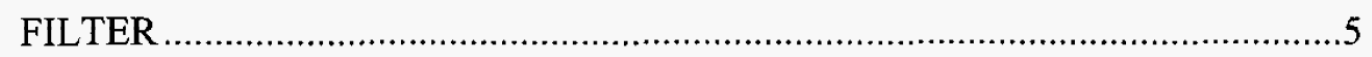

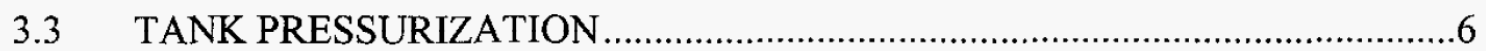

3.4 OVERALL OFFSITE RADIOLOGICAL CONSEQUENCE ..............................

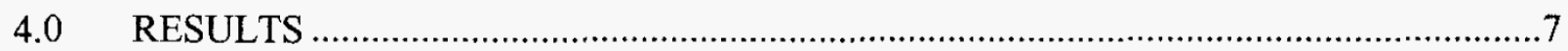

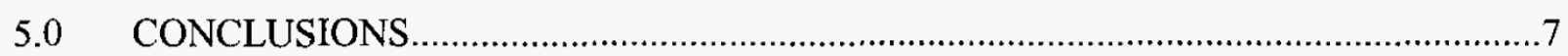

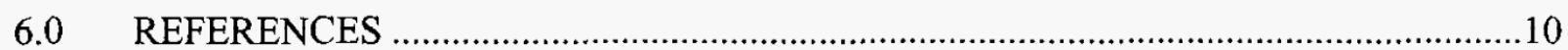

\section{APPENDICES}

A POTENTIAL FOR TANK FARM SYSTEMS TO GIVE OFF TOXIC CHEMICALS OR PRESSURIZE DUE TO CHEMICAL INCOMPATIBILITIES ...... A-i

B CHAPTER 2 OF FAI/01-07, AEROSOL GENERATION DURING SELECT NORMAL AND OFF-NORMAL WASTE TREATMENT PLANT PROCESSES .............. B-i

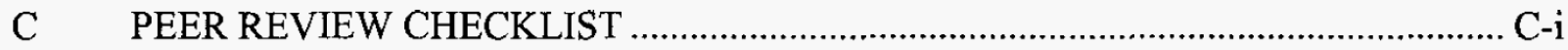




\section{RPP-9689 REV 4}

\section{LIST OF TABLES}

Table 4-1. Summary of Consequences Without Controls for Incompatible Materials................ 7

Table 5-1. Sensitivity of the Calculated Consequence to Analysis Assumptions and Input

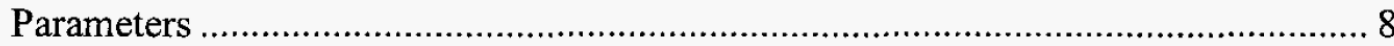


RPP-9689 REV 4

\section{LIST OF TERMS}

$\begin{array}{ll}\text { ARF } & \text { airborne release fraction } \\ \text { DST } & \text { double-shell tank } \\ \text { hEPA } & \text { high-efficiency particulate air (filter) } \\ \text { SST } & \text { single-shell tank } \\ \text { ULD } & \text { unit-liter dose }\end{array}$




\section{RPP-9689 REV 4}

This page intentionally left blank. 


\subsection{PURPOSE}

The purpose of this calculation note is to analyze the hazards related to chemical reactions that occur in waste tanks due to the addition of an incompatible material. Conditions were identified that resulted in toxic vapor generation and tank pressurization. The bounding incompatible material additions for offsite radiological consequences are discussed in Chapter 3.0.

\subsection{INTRODUCTION}

When considering various hazards within the tank farms, it was postulated that the mixing of incompatible material in a tank could result in a chemical reaction that generates toxic gases and vapors or generates sufficient pressure to expel headspace gases and aerosols. A number of hazardous conditions were examined that could result in gas or vapor production in a waste tank. Incompatible materials that could potentially be transferred to tank farm facilities were studied to determine a bounding case. The scenarios that were considered are as follows:

Scenario 1. Addition of an incompatible material due to a waste transfer from an internal or external source:

Case A. Misrouting or transfer of incompatible tank waste

Case B. Incompatible waste addition from external source.

Scenario 2. Inadvertent addition of an incompatible chemical due to a vendor or paperwork error when making a chemical addition to a tank:

Case A. Addition of excessive base to tank waste

Case B. Addition of acid to a waste tank.

Scenario 1, Case A. Because the wastes are similar from tank to tank, reactions due to a transfer from one tank to another will not result in significant generation of vapors or gases according to Reynolds (2001), "Potential for Tank Farm Systems to Give off Toxic Chemicals or Pressurize Due to Chemical Incompatibilities," which is reproduced in Appendix A. Therefore, Scenario 1, Case $\mathrm{A}$, was discarded as a potential bounding case.

Scenario 1, Case B. The majority of waste that is generated external to the tank farms would come from the Plutonium Finishing Plant, T Plant, and the 222-S Laboratory. Each of these facilities utilizes practices to ensure that the final facility waste solution is not transferred to a tank containing incompatible waste. Even if no credit is taken for these controls, the transfer lines are not compatible with strong acids (the most common incompatible material). Therefore, Scenario 1, Case B, was discarded as an unreasonable bounding case.

Scenario 2, Case A. The addition of excess base to tank waste also was examined for the potential to react and produce ammonia. Substantial amounts of ammonia are dissolved or trapped in some tank wastes. Ammonia is produced by the decomposition of nitrogen-containing 


\section{RPP-9689 REV 4}

compounds that were added to process solutions that eventually ended up as waste. Amine chelating agents such as ethylenediaminetetraacetic acid are among the chief sources. There is some potential for the ammonia in these wastes to be released into the vapor space of tanks and vented to the atmosphere.

The solubility of ammonia increases with decreasing $\mathrm{pH}$ due to an increasing fraction of the dissolved ammonia existing as the ammonium ion. As the $\mathrm{pH}$ is raised, the ammonium ion is converted to the neutral, molecular ammonia solute (aqueous $\mathrm{NH}_{3}$ ). The neutral aqueous ammonia desorbs to become gaseous or vapor phase ammonia. The main reactions are as follows:

$$
\begin{aligned}
\mathrm{NH}_{4}^{+}+\mathrm{OH}^{-} & \rightleftharpoons \mathrm{NH}_{3 \text { (aqueous) }}+\mathrm{H}_{2} \mathrm{O} \\
\mathrm{NH}_{3 \text { (aqueous) }} & \rightleftharpoons \mathrm{NH}_{3 \text { (vapor) }}
\end{aligned}
$$

The potential exists for strong bases to be accidentally added to waste tanks in amounts that may reduce the solubility of ammonia. A series of calculations was performed to predict the solubility of ammonia in a simulated waste and the effect of adding various amounts of $100 \%$ sodium hydroxide to the worst-case tank waste. It was found that a large amount of sodium hydroxide (slightly over $4 \mathrm{~g}$ moles/L of waste) must be added to reach the ammonia saturation point before any ammonia is released by the reaction. An estimate of the bounding ammonia release was calculated in WHC-SD-WM-CN-074, Chemical Reaction in a DCRT Leading to a Toxic Release. It was shown that the consequences of an ammonia release are well within conservative guidelines. Therefore Scenario 2, Case A, was not examined further.

Scenario 2, Case B. Because direct chemical additions can be made to the waste tanks, an accident was postulated in which bulk delivery of an unexpected chemical is made to a waste tank (e.g., instead of the caustic addition expected, the delivery truck contains an acid). Because the delivery was assumed to be from a large tanker truck, only common chemicals (acids, bases, and salts) that are routinely shipped in bulk quantities were considered. Common industrial acids were evaluated for their potential to react with tank waste resulting in gas or vapor generation. The reaction of strong acids with carbonate waste was found to produce large quantities of carbon dioxide. The reaction of acids with nitrite waste was also considered. It was postulated that the addition of acid could result in the release of nitrogen or an oxide of nitrogen. At basic conditions the production of one mole of nitrogen per two moles of $\mathrm{H}^{+}$ions is possible, while at acidic conditions the production of one mole of nitrogen oxide per mole of $\mathrm{H}^{+}$ions is possible. Thus, the reaction of acid with carbonate would be competing with the reaction of acid and nitrite as well as the neutralization reaction of acid with hydroxide. Experiments on the dissolution of waste with excess acid have been performed (Herting 2003, Final Report for Tank 241-C-106 Sludge Dissolution, Phase II). Waste from both single-shell tank (SST) 241-C-106 and double-shell tank (DST) 241-AY-102 was contacted with acid. DST 241-AY-102 waste contains similar quantities of nitrite and carbonate while SST 241-C-106 waste contains nearly 40 times more carbonate than nitrite. Samples of the gases generated by the experiments were collected and analyzed. It was found that carbon dioxide was nearly the only gas produced with traces of hydrogen also being detected at concentrations three to four orders of magnitude less than the carbon dioxide (oxides of nitrogen were not detected). Since the production of carbon dioxide was shown to be the dominant factor, the production of carbon dioxide was selected as the representative accident. The addition of concentrated sulfuric acid to the tank waste is 
examined for offsite radiological consequences from the aerosol released with the venting gases in Chapter 3.0.

\subsection{OFFSITE RADIOLOGICAL CONSEQUENCES}

The accident scenario, without controls, assumes that a cargo tanker filled with 5,000 gal of concentrated sulfuric acid $(18.7 \mathrm{M})$ is emptied into a DST or SST instead of the chemical expected (e.g., caustic or nitrite). The rate of addition is assumed to be $175 \mathrm{gal} / \mathrm{min}$. The receiving tank is assumed to contain sufficient carbonate waste to completely react with the incoming acid. The carbon dioxide formed is released into the tank headspace carrying with it a fraction of tank waste. It is assumed that the high-efficiency particulate air (HEPA) filters fail, contributing to the consequences. Condensation of the aerosol on the walls of the tank was assumed to be insignificant. The contributors to the radiological consequences are the HEPA filter release and the aerosolized waste.

\subsection{CONTRIBUTION OF AEROSOLIZED WASTE}

Sulfuric acid is a common industrial chemical. It is also typically transported at nearly $100 \%$ concentration $(18.7 \mathrm{M})$ to reduce costs and lower its corrosion potential. The reaction of sulfuric acid with sodium carbonate is shown below:

$$
\mathrm{H}_{2} \mathrm{SO}_{4}+\mathrm{Na}_{2} \mathrm{CO}_{3} \rightarrow \mathrm{CO}_{2(\text { gas) }}+\mathrm{Na}_{2} \mathrm{SO}_{4}+\mathrm{H}_{2} \mathrm{O}
$$

It can be seen that each mole of sulfuric acid would result in the generation of one mole of carbon dioxide.

Calculating the total release of carbon dioxide:

$(5,000 \mathrm{gal})(3.785 \mathrm{~L} / \mathrm{gal})(18.7 \mathrm{~g}$ moles $/ \mathrm{L})(44 \mathrm{~g} / \mathrm{g}$ mole $)=1.56 \times 10^{7}$ grams carbon dioxide $=1.56 \times 10^{4} \mathrm{~kg}$ carbon dioxide

$(5,000 \mathrm{gal})(3.785 \mathrm{~L} / \mathrm{gal})(18.7 \mathrm{~g}$ moles $/ \mathrm{L})(24.5 \mathrm{~L} / \mathrm{g}$ mole $)=8.67 \times 10^{6} \mathrm{~L}$ carbon dioxide

where:

$5,000 \mathrm{gal}=$ assumed volume of sulfuric acid addition

$3.785 \mathrm{~L} / \mathrm{gal}=$ conversion factor (CRC Handbook of Chemistry and Physics [Weast 1981])

$18.7 \mathrm{~g}$ moles $/ \mathrm{L}=$ molarity of concentrated $98 \%$ sulfuric acid (Weast 1981 )

$44 \mathrm{~g} / \mathrm{g}$ mole $\quad=$ molecular weight of carbon dioxide (Weast 1981).

$24.5 \mathrm{~L} / \mathrm{g}$ mole $=$ the volume of carbon dioxide gas at $25^{\circ} \mathrm{C}(298 \mathrm{~K})$

$=(22.4 \mathrm{~L} / \mathrm{g}$ mole at $273 \mathrm{~K})(298 \mathrm{~K} / 273 \mathrm{~K})$. 


\section{RPP-9689 REV 4}

The volume of aerosol carried off by the waste can be estimated using an entrainment coefficient E:

$$
\mathrm{E}=\text { Volume aerosol/Volume gas through the surface }
$$

At low superficial gas velocities discrete bubbles rise through the pool uniformly and steadily. This flow pattern is classified as the bubbly flow regime. When superficial gas velocity exceeds the threshold value $\left(j_{g, t}\right)$ the flow regime transitions from bubbly flow to churn turbulent flow which is characterized by nonuniform bubbles rising in a more random manner. The transitional superficial velocity can be found in chapter 2 of FAI/01-07, Aerosol Generation During Select Normal and Off-Normal Waste Treatment Plant Processes (reproduced as Appendix B):

$$
\mathrm{j}_{\mathrm{g}, \mathrm{t}}=0.3\left[(\sigma \mathrm{g}) /\left(\rho_{\mathrm{f}}\right)\right]^{1 / 4}=4.8 \times 10^{-2} \mathrm{~m} / \mathrm{s}
$$

where:

$\sigma$ is the liquid surface tension, $0.072 \mathrm{~kg} / \mathrm{s}^{2}$ for water against air at $25^{\circ} \mathrm{C}$ (Weast 1981) $\mathrm{g}$ is the gravitational constant, $9.81 \mathrm{~m} / \mathrm{s}^{2}$.

$\rho_{\mathrm{f}}$ is the assumed liquid density, $1.1 \times 10^{3} \mathrm{~kg} / \mathrm{m}^{3}$.

The superficial velocity $\left(\mathrm{j}_{\mathrm{g}}\right)$ for carbon dioxide generation can be calculated:

$$
\mathrm{j}_{\mathrm{g}}=\left[(9.1 \mathrm{~kg} / \mathrm{s}) /\left(1.8 \mathrm{~kg} / \mathrm{m}^{3}\right)\right]\left[(9.2 \mathrm{~m}) /\left(3.79 \times 10^{3} \mathrm{~m}^{3}\right)\right]=1.2 \times 10^{-2} \mathrm{~m} / \mathrm{s}
$$

where:

$$
\begin{array}{ll}
9.1 \mathrm{~kg} / \mathrm{s} & =\text { the carbon dioxide generation rate } \\
& =\left(1.56 \times 10^{4} \mathrm{~kg} \mathrm{CO} 2\right) /[\{(5,000 \mathrm{gal}) /(175 \mathrm{gal} / \mathrm{min})\}(60 \mathrm{~s} / \mathrm{min})] \\
9.2 \mathrm{~m} & =\text { depth of waste in tank [a full tank is assumed }] \\
3.79 \times 10^{3} \mathrm{~m}^{3} & =\text { waste volume }[1,000,000 \text { gal assumed volume }] \\
1.8 \mathrm{~kg} / \mathrm{m}^{3} & =\text { density of gas at } 25^{\circ} \mathrm{C}\left[(44.01 \mathrm{~kg} / \mathrm{kg} \text { mole }) /\left(24.5 \mathrm{~m}^{3} / \mathrm{kg} \text { mole }\right) .\right.
\end{array}
$$

Since the superficial velocity is less than the threshold velocity, the applicable flow regime is bubbly flow.

The source term used for the aerosol in this analysis is $10 \%$ DST sludge and $90 \%$ DST supernatant (which bounds the source terms in SSTs). Gas generation will occur in the vicinity of the incoming acid stream. The agitation caused by the gas generation will not cause the solid waste to be thoroughly mixed with the liquid. In addition, the solids will settle out as they pass through the liquid phase toward the surface. The inclusion of $10 \%$ solids in the aerosol is a conservative assumption. The radiological unit-liter dose (ULD) for the waste is from RPP-5924, Radiological Source Terms for Tank Farms Safety Analysis.

The waste aerosolized is calculated as follows:

$\left(8.67 \times 10^{6} \mathrm{~L}\right)\left(2.3 \times 10^{-7}\right)=2.0 \mathrm{~L}$ 


\section{RPP-9689 REV 4}

where:

$$
\begin{aligned}
2.3 \times 10^{-7}= & \text { bounding entrainment coefficient for } \mathrm{CaCO}_{3} \text { suspension in water } \\
& (\mathrm{FAI} / 01-07) .
\end{aligned}
$$

Given

$$
\begin{aligned}
& \text { ULD for DST liquids } \\
& \begin{aligned}
\text { ULD for DST solids } & =2.5 \times 10^{3} \mathrm{~Sv} / \mathrm{L}(\mathrm{RPP}-5924) \\
\text { ULD for aerosol } & =\left[\left(1.5 \times 10^{5} \mathrm{~Sv} / \mathrm{L}(\mathrm{RPP}-5924)\right.\right. \\
& \left.\left.\left.=3.04 \times 10^{4} \mathrm{~Sv} / \mathrm{L}\right)(0.9)\right]+\left[2.9 \times 10^{5} \mathrm{~Sv} / \mathrm{L}\right)(0.1)\right]
\end{aligned}
\end{aligned}
$$

Offsite aerosol dose $=($ aerosol released) (offsite $\chi / Q)$ (offsite ULD) (breathing rate)

$$
\text { Offsite } \begin{aligned}
\mathrm{D}_{\text {aerosol }} & =(2.0 \mathrm{~L})\left(2.22 \times 10^{-5} \mathrm{~s} / \mathrm{m}^{3}\right)\left(3.04 \times 10^{4} \mathrm{~Sv} / \mathrm{L}\right)\left(3.33 \times 10^{-4} \mathrm{~m}^{3} / \mathrm{s}\right) \\
& =4.5 \times 10^{-4} \mathrm{~Sv}
\end{aligned}
$$

where:

$2.22 \times 10^{-5} \mathrm{~s} / \mathrm{m}^{3}=$ offsite $\chi / \mathrm{Q}(\mathrm{RPP}-13482$, Atmospheric Dispersion Coefficients and Radiological/Toxicological Exposure Methodology for Use in Tank Farms)

$3.33 \times 10^{-4} \mathrm{~m}^{3} / \mathrm{s}=$ breathing rate (RPP-5924).

\subsection{CONTRIBUTION OF THE HIGH- EFFICIENCY PARTICULATE AIR FILTER}

Since a significant quantity of carbon dioxide is released, it is assumed that the tank pressurizes sufficiently to fail the HEPA filters.

Given

$$
\begin{aligned}
\text { DST HEPA filter release }= & 5.4 \times 10^{-5} \mathrm{~L} \text { at } 5 \% \text { solids (RPP-13437, Technical Basis } \\
& \text { Document for Ventilation System Filtration Failures } \\
& \text { Leading to an Unfiltered Release). }
\end{aligned}
$$

Given

$$
\begin{aligned}
& \text { ULD for DST solids }=2.9 \times 10^{5} \mathrm{~Sv} / \mathrm{L}(\mathrm{RPP}-5924) \\
& \begin{aligned}
\text { ULD for DST liquids } & =1.5 \times 10^{3} \mathrm{~Sv} / \mathrm{L}(\mathrm{RPP}-5924) \\
\text { ULD from HEPA } & \\
\text { filter release } & \left.=\left[\left(1.5 \times 10^{3} \mathrm{~Sv} / \mathrm{L}\right)(0.95)\right]+\left[2.9 \times 10^{5} \mathrm{~Sv} / \mathrm{L}\right)(0.05)\right] \\
& =1.59 \times 10^{4} \mathrm{~Sv} / \mathrm{L}
\end{aligned}
\end{aligned}
$$

Offsite HEPA dose $=$ (material released from HEPA) (offsite $\chi / \mathrm{Q}$ ) (ULD) (breathing rate)

$$
\begin{aligned}
\text { Offsite } \mathrm{D}_{\mathrm{HEPA}} & =\left(5.4 \times 10^{-5} \mathrm{~L}\right)\left(2.22 \times 10^{-5} \mathrm{~s} / \mathrm{m}^{3}\right)\left(1.59 \times 10^{4} \mathrm{~Sv} / \mathrm{L}\right)\left(3.33 \times 10^{-4} \mathrm{~m}^{3} / \mathrm{s}\right) \\
& =6.3 \times 10^{-9} \mathrm{~Sv}
\end{aligned}
$$




\section{RPP-9689 REV 4}

where:

$2.22 \times 10^{-5} \mathrm{~s} / \mathrm{m}^{3}=$ offsite $\chi / \mathrm{Q}(\mathrm{RPP}-13482)$.

$3.33 \times 10^{-4} \mathrm{~m}^{3} / \mathrm{s}=$ breathing rate (RPP-5924).

\subsection{TANK PRESSURIZATION}

It can be seen that the production of carbon dioxide reaches a significant volume. It was postulated that the rate of gas production would be sufficient to challenge the 55 to $60 \mathrm{lb} / \mathrm{in}^{2}$ gauge failure pressure for DSTs or the 11 to $12 \mathrm{lb} / \mathrm{in}^{2}$ gauge failure pressure for SSTs (WHC-SD-TWR-RPT-003, DELPHI Expert Panel Evaluation of Hanford High Level Waste Tank Failure Modes and Release Quantities).

The rate of production can be found by:

$(175 \mathrm{gal} / \mathrm{min})(3.785 \mathrm{~L} / \mathrm{gal})(1 \mathrm{~min} / 60 \mathrm{~s})(18.7 \mathrm{~g} \mathrm{moles} / \mathrm{L})(24.5 \mathrm{~L} / \mathrm{g}$ mole $)=5.06 \times 10^{3} \mathrm{~L} / \mathrm{s}$ $=5.06 \mathrm{~m}^{3} / \mathrm{s}$

where:

$175 \mathrm{gal} / \mathrm{min}=$ assumed rate of sulfuric acid addition

$3.785 \mathrm{~L} / \mathrm{gal}=$ conversion factor (Weast 1981)

$18.7 \mathrm{~g}$ moles $/ \mathrm{L}=$ molarity of concentrated $98 \%$ sulfuric acid (Weast 1981 )

$44 \mathrm{~g} / \mathrm{g}$ mole = molecular weight of carbon dioxide (Weast 1981)

$24.5 \mathrm{~L} / \mathrm{g}$ mole $=$ the volume of carbon dioxide gas at $1 \mathrm{~atm}\left(14.7 \mathrm{lb} / \mathrm{in}^{2}\right.$ absolute $)$ and $25^{\circ} \mathrm{C}(298 \mathrm{~K})$

$=(22.4 \mathrm{~L} / \mathrm{g}$ mole at $273 \mathrm{~K})(298 \mathrm{~K} / 273 \mathrm{~K})$.

Tank pressurization as a function of gas flowrate was calculated in HNF-4240, Organic Solvent Topical Report. When all the vents were considered it was found that it would take a flowrate of nearly $14 \mathrm{~m}^{3} / \mathrm{s}$ to pressurize a tank to $14 \mathrm{lb} / \mathrm{in}^{2}$ gauge $\left(28.7 \mathrm{lb} / \mathrm{in}^{2}\right.$ absolute). The number and geometry of vent paths vary from tank to tank; however, the tank presented in HNF-4240, used for the vent path calculation (241-C-103), is representative of all SSTs. For all SSTs, tank farm Engineering has judged the gas production rate is still bounded by the ventilation capacity at $11 \mathrm{lb} / \mathrm{in}^{2}$ gauge (conservatively estimated SST tank pressure [WHC-SD-TWR-RPT-003]). In order to compare volumetric flowrates of gaseous materials, they need to be adjusted to the same reference pressure. Converting the $14 \mathrm{~m}^{3} / \mathrm{s}$ flowrate at $28.7 \mathrm{lb} / \mathrm{in}^{2}$ absolute pressure to a pressure of $14.7 \mathrm{lb} / \mathrm{in}^{2}$ absolute $(1 \mathrm{~atm})$ results in a flowrate of $27 \mathrm{~m}^{3} / \mathrm{s}$. Thus, it can be seen that the production rate of carbon dioxide is less than a fifth of what is required to pressurize the tank to $14 \mathrm{lb} / \mathrm{in}^{2}$ gauge. The flowrate of carbon dioxide is estimated to pressurize the tank to $2.6 \mathrm{lb} / \mathrm{in}^{2}$ gauge. Therefore, any additional release due to tank failure is not considered credible. 


\subsection{OVERALL OFFSITE RADIOLOGICAL CONSEQUENCE}

Total offsite radiological consequences $=$ aerosol contribution + HEPA filter contribution

$$
\begin{aligned}
& \text { Offsite } \mathrm{D}_{\text {Total }}=\left(4.5 \times 10^{-4} \mathrm{~Sv}\right)+\left(6.3 \times 10^{-9} \mathrm{~Sv}\right)=4.5 \times 10^{-4} \mathrm{~Sv} \\
& =4.5 \times 10^{-2} \mathrm{rem} \text {. }
\end{aligned}
$$

\subsection{RESULTS}

Table 4-1 compares the accident consequences with the radiological consequence guidelines (Klein and Schepens, 2003, "Replacement of Previous Guidance Provided by RL and ORP"). Reviewing the consequences shows that the accident is considerably below the moderate consequence guideline of $1 \mathrm{rem}$; therefore, no safety-class equipment is required.

Table 4-1. Summary of Consequences Without Controls for Incompatible Materials.

\begin{tabular}{|c|c|c|c|}
\hline \multirow{2}{*}{ Case } & \multicolumn{3}{|c|}{ Offsite radiological consequences } \\
\cline { 2 - 4 } & $\begin{array}{c}\text { Calculated dose } \\
\text { (rem) }\end{array}$ & $\begin{array}{c}\text { Moderate consequence } \\
\text { guideline } \\
\text { (rem) }\end{array}$ & $\begin{array}{c}\text { High consequence } \\
\text { guideline } \\
\text { (rem) }\end{array}$ \\
\hline $\begin{array}{c}\text { Mixing of } \\
\text { incompatible } \\
\text { materials }\end{array}$ & $4.5 \times 10^{-2}$ & $1.0 \times 10^{+0}$ & $2.5 \times 10^{+1}$ \\
\hline
\end{tabular}

\subsection{CONCLUSIONS}

The offsite radiological consequences for the mixing of incompatible materials accident do not challenge the guidelines. Therefore, no safety-class structures, systems, and components have been identified to prevent or mitigate the risk associated with this accident.

The conclusion that the bounding mixing of incompatible materials accident does not challenge the evaluation guideline is robust against the uncertainties in the analysis. The sensitivity of the calculated consequence to assumptions and input parameters is evaluated in Table 5-1. It is concluded that no technical safety requirements are required to protect the assumptions and parameters used in the analysis. 
Table 5-1. Sensitivity of the Calculated Consequence to Analysis Assumptions and Input Parameters. (2 sheets)

\begin{tabular}{|c|c|c|c|}
\hline Assumption/input parameter & Sensitivity & $\begin{array}{l}\text { Protect } \\
\text { via TSR }\end{array}$ & $\begin{array}{l}\text { Protection } \\
\text { basis }\end{array}$ \\
\hline Acid is $18.7 \mathrm{M}$ sulfuric acid & $\begin{array}{l}\text { No anticipated effect on consequence bin. } \\
\text { Concentrated sulfuric acid is } 18.7 \mathrm{M} \text {. This is a } \\
\text { bounding assumption. }\end{array}$ & No & N/A \\
\hline $\begin{array}{l}\text { An addition rate of } 175 \text { gal of } \\
\text { acid per minute is assumed. }\end{array}$ & $\begin{array}{l}\text { No anticipated effect on consequence bin. Field } \\
\text { experience with actual chemical additions show } \\
\text { that addition rates are typically } 75-100 \mathrm{gal} / \mathrm{min} \text {. } \\
\text { Even if higher flowrates were postulated, the } \\
\text { analysis is insensitive to the increase. (The } \\
\text { flowrate would have to be increased by over two } \\
\text { orders of magnitude and transition into the churn } \\
\text { turbulent flow regime before the moderate } \\
\text { consequence guideline would be challenged.) }\end{array}$ & No & N/A \\
\hline $\begin{array}{l}\text { The source term used for the } \\
\text { aerosol in the analysis is } 10 \% \\
\text { DST solids and } 90 \% \text { DST } \\
\text { liquids. }\end{array}$ & $\begin{array}{l}\text { No anticipated effect on consequence bin. This is } \\
\text { a modeling assumption that cannot be verified but } \\
\text { is considered to be conservative because agitation } \\
\text { will occur in the vicinity of the incoming acid } \\
\text { stream. The agitation will not cause the solid } \\
\text { waste to be thoroughly mixed with the liquid. In } \\
\text { addition, the solids will settle out as they pass } \\
\text { through the liquid phase toward the surface. }\end{array}$ & No & N/A \\
\hline $\begin{array}{l}\text { The volume of the acid addition } \\
\text { was assumed to be } 5,000 \text { gal. } \\
\text { Based on the density of sulfuric } \\
\text { acid, this exceeds the allowable } \\
\text { gross vehicle weight for tanker } \\
\text { trucks. (While tanker trucks } \\
\text { contain a nominal capacity of as } \\
\text { much as } 7,000 \text { gal, they are } \\
\text { limited by total weight of the } \\
\text { filled tanker. Generally, the } \\
\text { maximum weight that can be } \\
\text { transported is } 45,000 \text { lb which } \\
\text { is the equivalent weight of } \\
3,000 \text { gal of sulfuric acid.) }\end{array}$ & $\begin{array}{l}\text { No anticipated effect on consequence bin. If } \\
\text { current transportation regulations were changed } \\
\text { to make larger shipments credible, the gas } \\
\text { generated would increase. The volume would } \\
\text { have to be increased to over } 100,000 \text { gal to } \\
\text { challenge the moderate consequence guideline. }\end{array}$ & No & N/A \\
\hline $\begin{array}{l}\text { The carbonate concentration is } \\
\text { assumed to be sufficient to fully } \\
\text { react with the sulfuric acid. }\end{array}$ & $\begin{array}{l}\text { No effect on consequence bin. Excess carbonate } \\
\text { will not increase the carbonate concentrations that } \\
\text { are insufficient to completely react with the } \\
\text { sulfuric acid would lower the consequences. }\end{array}$ & No & N/A \\
\hline $\begin{array}{l}\text { The bounding ULDs for liquids } \\
\text { and sludge from RPP- } 5924 \text { are } \\
\text { used. }\end{array}$ & $\begin{array}{l}\text { No anticipated effect on consequence bin. The } \\
\text { offsite radiological consequence is directly } \\
\text { proportional to the ULD. The ULDs would have } \\
\text { to be increased by a factor of approximately } 20 \\
\text { for the consequences to approach the moderate } \\
\text { consequence guideline. This increase is not } \\
\text { considered credible for authorized activities. }\end{array}$ & No & N/A \\
\hline
\end{tabular}




\section{RPP-9689 REV 4}

Table 5-1. Sensitivity of the Calculated Consequence to

Analysis Assumptions and Input Parameters. (2 sheets)

\begin{tabular}{|c|c|c|c|}
\hline Assumption/input parameter & Sensitivity & $\begin{array}{l}\text { Protect } \\
\text { via TSR }\end{array}$ & $\begin{array}{l}\text { Protection } \\
\text { basis }\end{array}$ \\
\hline $\begin{array}{l}\text { A breathing rate of } \\
3.33 \times 10^{-4} \mathrm{~m}^{3} / \mathrm{s} \text { from RPP }-5924 \\
\text { is used. }\end{array}$ & $\begin{array}{l}\text { No anticipated effect on consequence bin. The } \\
\text { breathing rate is only applicable to radiological } \\
\text { releases. The radiological consequences are well } \\
\text { below guidelines and the breathing rate would } \\
\text { have to be increased by a factor of } 20 \text { to } \\
\text { challenge the consequences, which is not } \\
\text { considered credible. }\end{array}$ & No & N/A \\
\hline $\begin{array}{l}\text { An atmospheric dispersion } \\
\text { coefficient of } 2.22 \times 10^{-5} \mathrm{~s} / \mathrm{m}^{3} \\
\text { was used (RPP-13482). }\end{array}$ & $\begin{array}{l}\text { No anticipated effect on consequence bin. The } \\
\text { atmospheric dispersion coefficient represents the } \\
95^{\text {th }} \text { percent overall value. No credit is taken for } \\
\text { either plume meander or deposition. }\end{array}$ & No & N/A \\
\hline $\begin{array}{l}\text { The pressurization resulting } \\
\text { from the accident fails the } \\
\text { HEPA filters. }\end{array}$ & $\begin{array}{l}\text { No anticipated effect on consequence bin. If the } \\
\text { HEPA filters do not fail, even with no credit for } \\
\text { waste retention, the consequences would be } \\
\text { decreased since there would be no contribution } \\
\text { from the failed filters. }\end{array}$ & No & N/A \\
\hline $\begin{array}{l}\text { The inventory on the HEPA } \\
\text { filters is equivalent to that } \\
\text { which would produce a contact } \\
\text { dose rate of } 200 \mathrm{mrem} / \mathrm{h} \text {. This } \\
\text { is a modeling assumption based } \\
\text { on current tank farm practices. }\end{array}$ & $\begin{array}{l}\text { No anticipated effect on consequence bin. The } \\
\text { contribution from the HEPA filters is } \\
\text { insignificant to the overall consequences. The } \\
\text { contribution of the HEPA filters would have to } \\
\text { increase by over seven orders of magnitude for } \\
\text { offsite guidelines to be exceeded. }\end{array}$ & No & N/A \\
\hline $\begin{array}{l}\text { No credit is taken for } \\
\text { condensation or plate-out of } \\
\text { aerosol on the walls of the tank. }\end{array}$ & $\begin{array}{l}\text { No anticipated effect on consequence bin. Any } \\
\text { plate-out would cause the consequences to } \\
\text { decrease. }\end{array}$ & No & N/A \\
\hline $\begin{array}{l}\text { Tank is assumed to contain } \\
1,000,000 \text { gallons of waste. }\end{array}$ & $\begin{array}{l}\text { No anticipated effect on consequence bin. The } \\
\text { analysis is insensitive to the volume of waste and } \\
\text { no credit is taken for dilution in the headspace. }\end{array}$ & No & N/A \\
\hline $\begin{array}{l}\text { The bounding entrainment } \\
\text { coefficient for a } \mathrm{CaCO}_{3} \\
\text { suspension in water was } \\
\text { selected from } \mathrm{FAI} / 01-07 \text {. }\end{array}$ & $\begin{array}{l}\text { No anticipated effect on consequence bin. The } \\
\text { entrainment coefficient would have to be } \\
\text { increased by more than an order of magnitude to } \\
\text { challenge the moderate consequence guideline. }\end{array}$ & No & $\mathrm{N} / \mathrm{A}$ \\
\hline
\end{tabular}

\section{Notes:}

FAI/01-07, 2001, Aerosol Generation During Select Normal and Off-Normal Waste Treatment Plant

Processes, Rev. 0, Fauske \& Associates, Inc., Burr Ridge, Illinois.

RPP-5924, 2003, Radiological Source Terms for Tank Farms Safety Analysis, Rev. 3, CH2M HILL Hanford

Group, Inc., Richland, Washington.

RPP-13482, 2003, Atmospheric Dispersion Coefficients and Radiological/Toxicological Exposure

Methodology for Use in Tank Farms, Rev. 2, CH2M HILL Hanford Group, Inc., Richland, Washington.

$\mathrm{ARF}=$ airborne release fraction.

DST = double-shell tank.

N/A $=$ not applicable.

TSR $=$ technical safety requirement.

ULD = unit-liter dose. 
RPP-9689 REV 4

\subsection{REFERENCES}

FAI/01-07, 2001, Aerosol Generation During Select Normal and Off-Normal Waste Treatment Plant Processes, Rev. 0, Fauske \& Associates, Inc., Burr Ridge, Illinois.

Herting, D. L., 2003, Final Report for Tank 241-C-106 Sludge Dissolution, Phase II, (letter FH-0301877 to D. A. Reynolds, CH2M HILL Hanford Group, Inc., dated May 8) Fluor Hanford, Richland, Washington.

HNF-4240, 2000, Organic Solvent Topical Report, Rev. 1, CH2M HILL Hanford Group, Inc., Richland, Washington.

Klein, K. A., and R. J. Schepens, 2003, "Replacement of Previous Guidance Provided by RL and ORP” (letter 03-ABD-0047 to E. K. Thomson, Fluor Hanford Inc., and E. S. Aromi, CH2M HILL Hanford Group Inc., February 4), U.S. Department of Energy, and Office of River Protection, Richland, Washington.

Reynolds, D. A., 2001, "Potential for Tank Farm Systems to Give off Toxic Chemicals or Pressurize Due to Chemical Incompatibilities" (interoffice memo 7G300-01-MAK-027 to K. R. Sandgren, October 9), CH2M HILL Hanford Group, Inc., Richland, Washington.

RPP-5924, 2003, Radiological Source Terms for Tank Farms Safety Analysis, Rev. 3, CH2M HILL Hanford Group, Inc., Richland, Washington.

RPP-13437, 2005, Technical Basis Document for Ventilation System Filtration Failures Leading to an Unfiltered Release, Rev. 1, CH2M HILL Hanford Group, Inc., Richland, Washington.

RPP-13482, 2003, Atmospheric Dispersion Coefficients and Radiological/Toxicological Exposure Methodology for Use in Tank Farms, Rev. 2, CH2M HILL Hanford Group, Inc., Richland, Washington.

Weast, R. C., 1981, CRC Handbook of Chemistry and Physics, $61^{\text {st }}$ Ed., CRC Press, Inc., Boca Raton, Florida.

WHC-SD-TWR-RPT-003, 1996, DELPHI Expert Panel Evaluation of Hanford High Level Waste Tank Failure Modes and Release Quantities, Rev. 0, Westinghouse Hanford Company, Richland, Washington.

WHC-SD-WM-CN-074, 1997, Chemical Reaction in a DCRT Leading to a Toxic Release, Rev. 0-A, Westinghouse Hanford Company, Richland, Washington. 
RPP-9689 REV 4

\section{APPENDIX A}

POTENTIAL FOR TANK FARM SYSTEMS TO GIVE OFF TOXIC CHEMICALS OR PRESSURIZE DUE TO CHEMICAL INCOMPATIBILITIES 


\section{RPP-9689 REV 4}

This page intentionally left blank.

A-ii 


\section{APPENDIX A}

\section{POTENTIAL FOR TANK FARM SYSTEMS TO GIVE OFF TOXIC CHEMICALS OR PRESSURIZE DUE TO CHEMICAL INCOMPATIBILITIES \\ INTEROFFICE MEMO \\ CH2MHILL \\ Hanford Group, inc.}

\begin{tabular}{|c|c|c|}
\hline $\begin{array}{l}\text { From: } \\
\text { Phone: } \\
\text { Date: } \\
\text { Subject: }\end{array}$ & \multicolumn{2}{|c|}{$\begin{array}{l}\text { Process Control } \\
373-3115 \\
\text { October } 9,2001 \\
\text { POTENTIAL FOR TANK FARM SYSTEMS TO } \\
\text { CHEMICALS OR PRESSURIZE DUE TO CHEN }\end{array}$} \\
\hline To: & K. R. Sandgren & R1-49 \\
\hline Copies: & $\begin{array}{l}\text { M. A. Knight } \\
\text { DAR File/LB }\end{array}$ & R2-11 \\
\hline
\end{tabular}

References: 1. RPP-491, "Methodology for Predicting Flammable Gas Mixtures in DoubleContained Receiver Tanks," Revision 0-B, dated November 2000.

2. PNN-11702, "Chemical Pathways for the Formation of Ammonia in Hanford Wastes," Revision. I, dated December 1997.

3. Internal Memo, D. A. Reynolds, to G. L. Dunford, "Potential for Reactions Due to Chemical Incompatibility, 74A30-96-025, dated June 25, 1996.

4. Internal Memo, S. J. Beard to L. W. Roddy, "Operation of Mechanical and Electrical Equipment in Tank 102-C during Zirflex Campaign," dated July $6,1967$.

Reference 3 addresses the fact that waste stored at the tank farms, and in particular the doubleshell tanks, is a mixture of wastes amassed over the past 50 years. It was surmised that further blending of the waste with other blended waste would not cause chemical reactions as a result of chemical incompatibility. Reference 3 also addressed the possibility of an acid-base reaction should acid be inadvertently added to the waste. It was determined that the neutralization of the waste would not generate enough heat to bring the temperature beyond the current tank temperature limits.

The purpose of this memo is to respond to a request from Nuclear Safety organization to broaden the discussion in Reference 3 with the focus on toxic chemical releases, the possibility of tank pressurization, and address the smaller tanks used for processing and transfers (DCRTs, etc.). This assessment will look at these aspects and provide broad base answers for identified focus areas. Certain special cases will be discussed.

Toxic Gases

For all practical purposes, toxic gases usually means ammonia $\left(\mathrm{NH}_{3}\right)$ in the tank farms. It is recognized that other organic gases are occasionally released, but to a lesser extent to that of ammonia.

Ammonia has been studied extensively for the flammable gas program. Frequently the information is for flammability purposes but usually simple conversions can be performed to translate the information into toxic data. It has been shown in Reference 1 that ammonia cannot be discounted for small tanks with low ventilation rates and small headspaces. 
Ammonia has been used at Hanford as a process chemical and safe handling of ammonia has always been a concern. B Plant used ammonia carbonate as an eluent for an ion exchange with subsequent recovery by evaporation and adsorption. PUREX used ammonium fluoride /ammonium nitrate (AFAN) as a declading chemical during the Zirflex Processing. The waste from PUREX eventually went in to the tank farm. Both in 1967 and in 1987, the Zirflex waste caused high levels of ammonia in the tank farms. In 1967, tank 241-C-102 recorded a maximum concentration of $2 \%(20,000 \mathrm{ppm})$ (Reference 4). In 1987, the stack from the $\mathrm{AW}$ farm recorded up to $2000 \mathrm{ppm}$. The tank farms again received large amounts of ammonia when PUREX sent the ammonia scrub solution to 241-AP farm instead of to the cribs.

In 1987, a Zirflex waste evaporator campaign was shut down when the evaporator stack releases exceeded $100 \mathrm{lbs} /$ day ammonia. Ammonia was a concern when the ammonia scrub solution from AP farm was being evaporated as well.

Currently tanks 241-AW-103 and 241-AW-105 contain high ammonia concentrations from past processing campaigns. It has been determined that all other waste also has ammonia but it is derived from slow chemical reactions that are probably coupled with radiation. Reference 2 gives some plausible mechanisms for these reactions. The ammonia is produced slowly and has the potential of being released to the tank headspace as it is made. As long as the $\mathrm{pH}$ of the waste is greater than 8 , the ammonia will exist as dissolved ammonia - not as ammonium ion. This limits the quantities that can be stored in the waste but does promote rclease of the ammonia to the tank headspace. Because all the waste in the tank farms is greater than $\mathrm{pH} 8$, there is no chemical driver to release ammonia when wastes are co-mingled. Ammonia will be released based on a Henry's Law solubility relationship. However, ammonia will be released when the waste is disturbed. Waste transfers where the waste falls through the headspace of a tank or when an airlift circulator is operated are examples of waste disturbing activities that may cause the ammonia in the waste to be released. What drives the ammonia release is when waste is pumped from deep in a tank, under about 2 atmospheres of pressure, is released into the dome of a tank that is at $l$ atmosphere in pressure. The pressure difference will be a driving force under the Henry's Law solubility relationship. Reference 1 takes this into account.

Double-shell tanks are actively ventilated which sweeps the release ammonia from the tanks. This controls the concentration of ammonia to acceptable levels. Ammonia has been monitored on certain of the double-shell tanks for the flammable gas program. Except for the occasions when tank 24l-SY-101 had a gas release event, the ammonia levels in double-shell tanks have been acceptable.

On at least one occasion, mechanically disturbing the waste caused an organic vapor problem. This occurred during the sluicing of tank 241-C-106. It was determined that the organics trapped or dissolved in the waste were released when the waste was disturbed. This clearly shows that mechanical disturbing the waste, not a chemical incompatibility, caused such releases.

Mechanical disturbances to the waste, such as transfers, lancing, etc., only disturb small portions of the waste at a time. These small portions do not contain enough total inventories of toxic materials to be a hazard outside of the tank farm. There have been complaints inside of tank farms over strong "odors." No instances have been reported of problems outside of the tank farms. The initial running of the mixer pump in tank 241-SY-101 had the largest potential for 
releasing large amounts of toxic gasses. This activity was carefully monitored and did not release toxics beyond guidelines for the 100 -meter person.

There have been no releases of ammonia that can be attributed to chemical reactions due to blending waste. All of the instances of ammonia release can be shown to be the result of mechanical disturbance and Henry's Law equilibriums. This is because the waste is all basic and the ammonia is not in an ionic form such as ammonium. The ammonia is merely dissolved in the waste and needs no chemical reaction to cause a release. The same applies to volatile organics.

\section{Pressure}

The only recognized mechanism for a chemical reaction to cause pressurization would be to mix an acid with the waste. This would cause carbon dioxide to be released from the waste. As long as the $\mathrm{pH}$ stays greater than 7 , the carbon dioxide will be in ionic forms such as carbonate and bicarbonate and will not be released to the tank headspace. There is no known mechanism for the waste in the tank farm system to release significant quantities of gas, from chemical reactions, during mixing and transfers. The addition of acid would be considered an off-normal situation.

Tanks can be pressurized by temperature changes. Typically, hot slurry from the evaporator is dumped through the headspace of a colder tank. The hot slurry rapidly heats the dome space air that increases in volume. The volume increase is rapid enough to overcome the ventilation rate and the tank pressurizes. The pressure decays rapidly as the ventilation catches up but occasionally the transfer will automatically terminate from a high-pressure alarm.

This pressurization is of no consequence for toxic gas. The slurry from the evaporator has been through a rather high vacuum (60 Torr) with heat and steam flow. This will strip off the ammonia and other toxic gases in the evaporator and which are treated at the evaporator. The hot stream into a tank dome will be devoid of toxic gases.

No instances of radioactivity release have ever been measured from these small short-term pressurizations. For nearly two decades, tank 241-SY-101 would pressurize from a different mechanism approximately once a year. The tank 241-SY-101 pressurization events would typically last up to 20 minutes. Each time this happened, the farm was surveyed for radioactivity. No contamination was ever found that could be attributed to the pressurization event. Apparently, these short-term low pressurizations do not promote radioactive discharges.

\section{Small Tanks}

The tank farm operations have 177 tanks that store waste. In addition, there are a number of smail tanks that may contain waste but their main function is usually to transfer the waste to other storage tanks. These small tanks include the double-contained receiver tanks (DCRT's), the catch tanks and the IMUST's. Many of these tanks do not have a current mission but others will be used in the foreseeable future. 


\section{RPP-9689 REV 4}

K. R. Sandgren

7G300-01-MAK-027

Page 4

October 9,2001

Blending and commingling waste as described in Reference 3 will apply to these small tanks as well as the storage tanks. Chemical incompatibilities are not going to occur in these tanks from commingling waste in them. The acid-base reaction discussed in Reference 3 also applies to these small tanks. Commingling is not expected to cause any pressurization or radioactive releases.

The DCRT 244-TX is to receive waste from the laboratories and the Plutonium Finishing Plant The Compatibility Program Plan governs receipt of these wastes and is designed to protect against incompatibles.

The main concern with these small tanks is the ammonia release. The small tanks have a static headspace that ammonia could buildup to toxic levels. Reference 1 has identified this to be a potential problem. The dilution factor for waste being jet pumped into the DCRT's is frequently set to control the ammonia. High ammonia concentrations have been found in catch tank headspaces. The high ammonia concentrations are not caused by incompatible material but rather the Henry's law release of ammonia. The high ammonia concentrations are reached because of the lack of positive ventilation. This phenomenon is also found in single-shell tanks that have static ventilation.

One special case is the 244- vaults. These vaults were used to acidify the waste before feeding to B Plant. Each vault contains several small tanks that hold waste that has not been characterized. Current plans are to consolidate all waste into a single tank in the vault before transferring to the tank farms. The consolidation of the waste to a single tank is, perhaps, the only situation that has the potential for blending an acid waste with a basic waste. The blending will not be any worse than the scenario discussed in Reference 3. It could only happen if one of the tanks were left with waste in an acid state. This special case of the 244-vaults will be analyzed during the project safety analysis.

If you have any question on the material present here, feel free to call D. A. Reynolds, 375-3115.

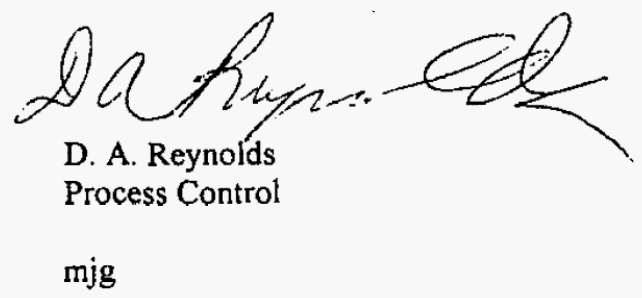


RPP-9689 REV 4

\section{APPENDIX B}

CHAPTER 2 OF FAI/01-07, AEROSOL GENERATION DURING SELECT NORMAL AND

OFF-NORMAL WASTE TREATMENT PLANT PROCESSES
\end{abstract}


RPP-9689 REV 4

This page intentionally left blank.

B-ii 


\section{APPENDIX B}

CHAPTER 2 OF FAI/01-07, AEROSOL GENERATION DURING SELECT NORMAL AND OFF-NORMAL WASTE TREATMENT PLANT PROCESSES

$$
\text { 苜 }
$$

Fauske A Assuclater, Inc.

\section{FAX Transmittal}

DATE: September 25, 2003

TO: Kevin

co.:

HAX NO.: (509) 373-6101

FROM: Mike Epstein

SUBJECT: Chapter 2 of EAl/01-07

Transmittal equals 11 page(s) - including this cover sheet

MESSAGE:

16 W070 West 83rd Street - Burr Ridge, Illinots 60527 - (630) 323-8750

Telefax: (630) 986-5481 - E-mail; fai Orfuuske.com 
$2-1$

\subsection{MECHANCALABROSOL RRODUCTON ABOVE SELE-BOILING OR BUBBLNG WASTE IN VESYELS}

\subsection{Entralment Coefirelent and Babbiline Flox Redima}

When boiling or bubbling occurs in a liquid pool, droplets are ejected from the pool surface by bursting of bubbles or by intense liquid agitation, depending on the magnitude of the bubble flow rate. The droplets ejocted from the surface have various diameters. Here wo are interested in those droplots whose diameters are small enough to be carriod away by tho streuming gas or vapor to any hoight above the liquid pool. The process of separation of liquid from the pool and subsequent transport by the flowing gas is referred to as liquid entrainment. The volume or flow rate of liquid aerosol that is carriod upward is related to the volurie or flow rate of gas or vapor by the definition of the entrainmeat coefficient $E$ :

$$
\frac{V_{1}}{V_{1}}=\frac{j_{2}}{j_{z}}=E
$$

In the above equation $\mathrm{V}_{\mathrm{h}}$ is the volume of liquid drops (acrosol) produced at the surface due to the passage of volume $V_{2}$ of gas (vepor) through the surface, $j_{r}$ is the upward auperficial volocity of liquid floping as droplets and $j_{8}$ is the aupcrficial volocity of gas (vapor).

At low superficial gas velocities discrele bubbles rise through the pool uniformly and steadily. This flow pattern has been classified as the bubbly flow regime. When the superficial gas velocity excecds the threshold value $j_{2}$ the flow segime transitions from bubbly flow to churn turbulont flow which is characterized by nonuniformed sized bubbles rising unstondily and chaotically. The transition supcrficial yolocity is (Wallis, 1962)

$$
j_{g, t}=0.3\left(\frac{\sigma g}{p_{r}}\right)^{1 / 4}
$$


where $\sigma$ is the liquid aurface tencion, $p_{g}$ in tha liquid density, and $g$ is the grevitational constmat. For an air-water system $\left(\sigma=0.07 \mathrm{~kg} \mathrm{~s}^{-2}, p_{i}=10^{3} \mathrm{~kg} \mathrm{~m}^{-3}\right)$ the transition from bubbly to chum turbulent flow occurs at about $j_{g, t}-5.0 \mathrm{~cm} \mathrm{~s}^{-1}$.

\subsection{Bubhly Flon Redme and Bubple Burut Mechenism of Aeronol Froctuction}

In the bubbly flow regime, discrete bubbles rise up to the surface of the pool and collapese there. The mochanism of aerosol generation is the rupture of the dome-shaped lamina that forms above the bubble as it passes through the pool surface. The discussion which follows focuses on the catrainment coefficient $E$ for the bubble burst process. The estimates of $B$ which are suggested by the available information are empirical rather than basod on first principles.

Tomaides and Whitby (1976) reported a waler aerosol size distribution measurement resulting from the collagse of an isolated $0.55-\mathrm{cm}$ diamcter bubble at the surface of a $0.1 \%$ aqueous solution of $\mathrm{NaCl}$. About 200 droplets were observed. The droplel size distribution data were presented by plotting the droplet number frequenoy $\Delta N /(N-\Delta d)$ versus the drop diameter $d$, where $\Delta N$ is the number of droplets in the size range $d$ to $d+\Delta d$ und $N$ is the total number of droplets $(-200)$. Most of the contribution to the distribution comes from the size range 1.0 to $10.0 \mu \mathrm{m}$ and over this range the present anthor found that the distribution is well-represented by the power law

$$
\frac{\Delta N}{N \cdot \Delta d}=\frac{0.3}{d^{0.122}} \quad \text { for } \quad 1.0 \leq d \leq 10.0 \mu m
$$

T.eting $\Delta \mathrm{N}$ and $\Delta d$ approach zero the total volume of the aerosol is 


\section{RPP-9689 REV 4}

$$
\begin{aligned}
V_{1} & =\sum_{i} \Delta N_{1} \frac{4}{3} \pi\left(\frac{d_{1}}{2}\right)^{3}=\int_{1.0}^{1000} \frac{4 \pi}{3}\left(\frac{d}{2}\right)^{1} \frac{0.3}{d^{0.033}} \mathrm{Nd}(\mathrm{d}) \\
& =0.049 \mathrm{~N} \int_{1.0}^{10.0 \mathrm{~mm}} \mathrm{~d}^{3.173}=1.47 \times 10^{4} \mu \mathrm{m}^{3}
\end{aligned}
$$

The volume of the $0.55-\mathrm{cm}$ diameter bubble is $V_{k}=8.71 \times 10^{10} \mu \mathrm{m}^{3}$. Thus the entrainment cocfficient inferred from the measurements of Tomaides and Whitby (1976) is, from Eq. (2-1),

$$
E=\frac{1.47 \times 10^{4}}{8.71 \times 10^{10}}=1.7 \times 10^{-9} \quad(0.1 \% \mathrm{NaCl} \text { solution })
$$

Gamer et al. (1954) meanured the vohume of the aerosol drops produced above aingle bursting bubbles in the 6.0 to $12.0 \mathrm{~mm}$ range in water containing a susponsion of calcium carbonute and in a $12 \%$ aqucous $\mathrm{kNO}_{2}$ solution. The measured entrainment coefficients were in the range

$$
\begin{array}{ll}
B=1.3 \times 10^{-7}-2.3 \times 10^{-7} & \left(\mathrm{CaCO}_{3} \text { suspension in water }\right) \\
\mathrm{B}=3 \times 10^{-7}-10^{-6} & \left(12 \% \mathrm{kNO}_{3} \text { solution }\right)
\end{array}
$$

In the same luburalory study Gamer et al. (1954) also messured entrainment coofricients for single bubbles in pure water, ethyl sicohol and bonzene. The results were

$$
E=2 \times 10^{-5} \text { to } 5 \times 10^{-5} \quad \text { (pure liquids) }
$$

Ciprisno and Blunchard (1981) porformed a multi-bubble experiment in sea water $(-3.5 \%$ $\mathrm{NaCl}$ ). A continuous watertall plunged through the surface of a pool of sea water thereby producing a plume of bubbles within the sea watcr. This multi-bubbling situation produced a wide droplet sizo distribution relative to the distribution observed by Tomaides and Whilby (1976) in their single-bubble/salt solution experiment, 1.0 to $50 \mu \mathrm{m}$ versus 1.0 to $10 \mu \mathrm{m}$. 


\section{RPP-9689 REV 4}

reppectively. When summed over the entire 1.0-50 $\mathrm{mm}$ distribution, the drop volume production rate is $5.08 \times 10^{-4} \mathrm{~cm}^{3} \mathrm{~s}^{-1}$. By capturing the air contributed by all the burating bubbles, Clpriano and Blenchard determined that the total rate of air entrainment was $128 \mathrm{~cm}^{3} \mathrm{~B}^{-1}$; therefore (see Eq. 2-1)

$$
\mathrm{B}=4,0 \times 10^{-6} \quad \text { (multi-bubble/3.5\% NaCl solution) }
$$

Interestingly enough, if only the drops in the interval 1.0-10 $\mu \mathrm{m}$ are counted the entrainment cocflicient becomes $\mathrm{E}-1.5 \times 10^{-7}$ which is about cqual to that messurcd by Tomaides and Whitby (200:Eq. 2-5).

Azbel (1978) developed a model to predict the mass of the liquid film which surrounds the ges bubble at the instant of bubble break-through at the pool surface. The effect of impurities is not included in Azbel's model, yet for no apparent rosison his theoretical formula for $E$ agrees with the Gamer et al. (1954) water/CaCO 3 suspension data and the Tomaides and Whitby (1976) salt solution data.

It is clear from the available empirical information on aerosol production by bubble burst that entrainment rates for pure liquids are about two orders of magnitude larger than those for liquids containing forcign substances (sce Fig. 2-1). For pure liquids the measure entrainment coefficient is in the range $\mathrm{B}=2 \times 10^{5}$ to $5 \times 10^{-5}$. When impurities are present in the liquid and only ejected droplets of size $<10 \mu \mathrm{m}$ are considered, $\mathrm{E}=10^{-7}$ to $10^{-6}$ depending on the type of impurity. The bubble burst data obtained with $\mathrm{CaCO}_{3}$ suspension and rather dilute $\mathrm{NaCl}$ solutions yiqlded $\mathrm{E}-2 \times 10^{-7}$ while the data obtained with $\mathrm{KNO}_{3}$ solutions resulted in $\mathrm{E}-3 \times 10^{\circ}$ $71010^{-6}$. Effects of impuritics on acrosol generation have also been observed by Mecintyre (1974) and Day (1964). It is worth mentioning that tests with pure glycerol (Gamer et al., 1954) ahowed very low droplet production. This was attributed to the high viscosity of the glycerol. In clcan inviscid liquids bubbles burst immodietcly upon arrival at the surface. High visoosity, the presence of dissolved or suspended particles results in stabilizing the bubble at the surface. The delay before nupture appears to reduce drop production relative to drop proctuction above clean liquids. Additional bubble burst data is needed using fluids more nearly prototypic of process- 
RPP-9689 REV 4

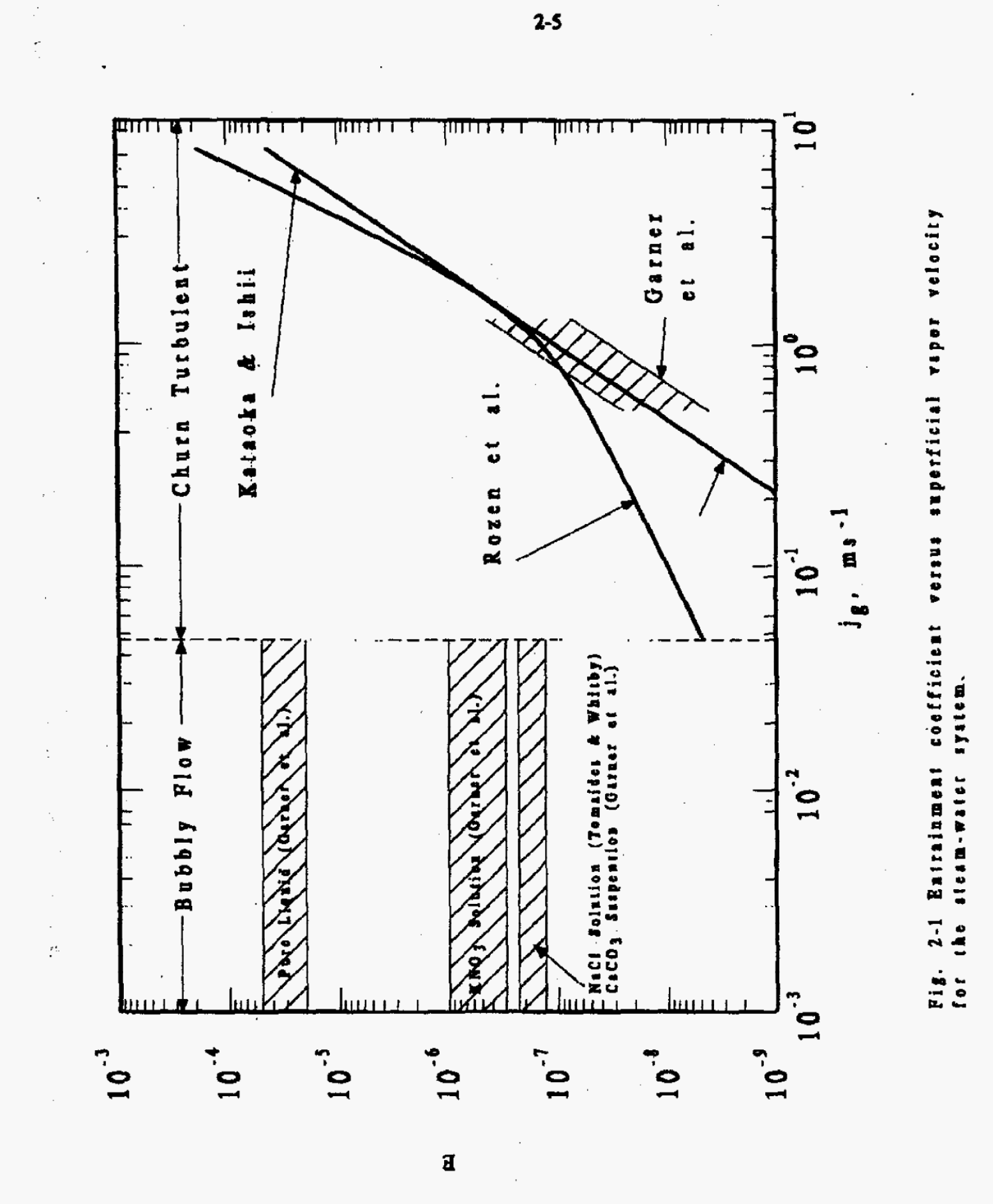

.

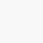

\begin{abstract}
.
\end{abstract}
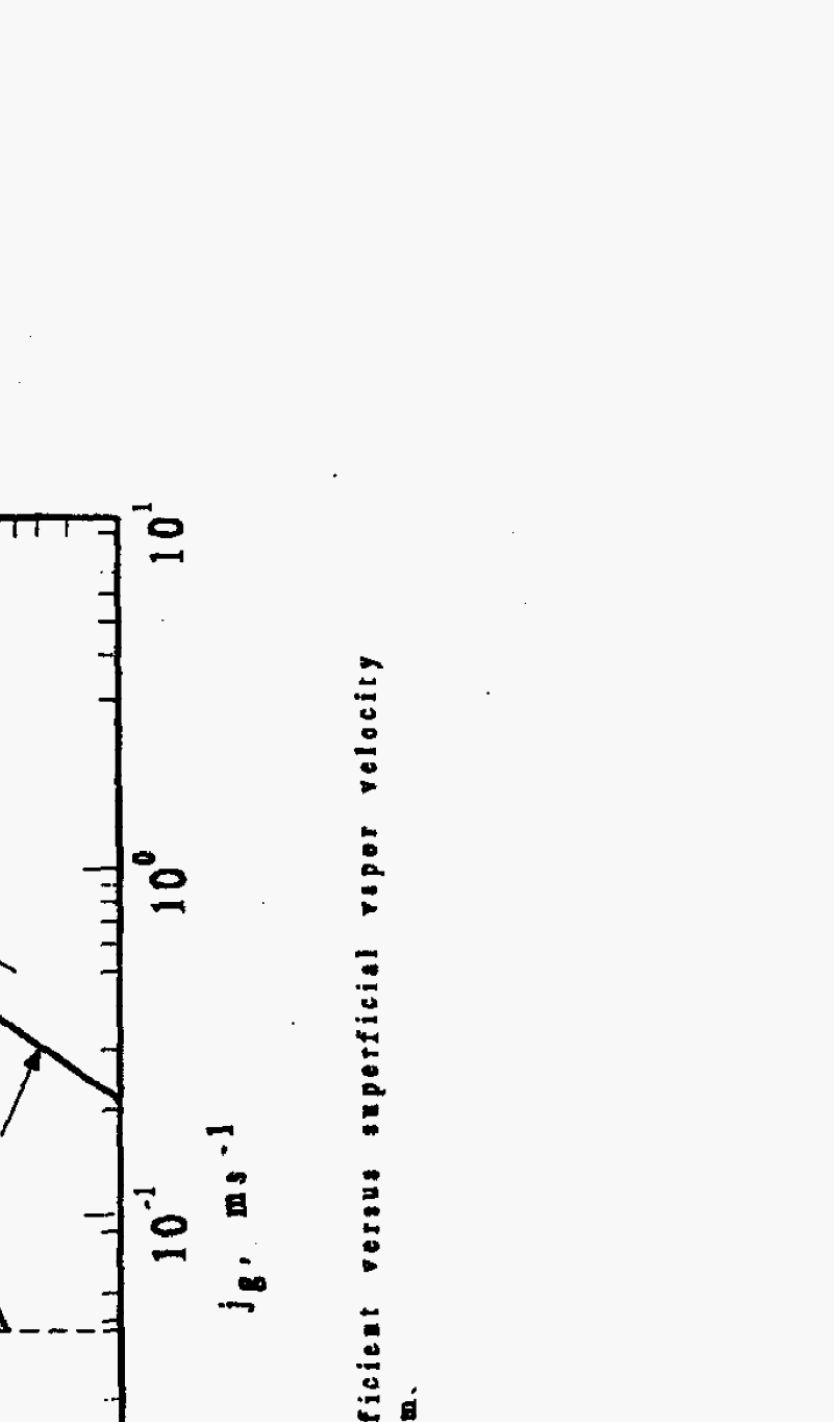


\section{RPP-9689 REV 4}

\section{6}

waste liquid. Until such dats becomes available, the valuo $\mathrm{B}=2 \times 10^{-7}$ is recoenmended for waste liquid. This is a beat estimele value that reflects the high concentrations of impuritics that are likely to be dissolved andor sumpended in the waste liquid.

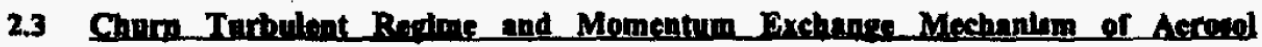 Brotipation}

In the chum turbulent flow regime the droplets are not generated by the bubble burnt mochanism, but by a momentum exchenge mechanism. Rozen et al. (1974) measured the aorosol flux. in a water-air system for air superficial velocilies in the range $0.6<j_{4}<3.0 \mathrm{~m} \mathrm{~s}^{\prime}$. The data is cloarly representative of chum flow conditions. The entrainment coefficient just above the pool surface was abown experimentally to be independent of gas filux and given by $E=$ 4ps/pr. Rozen et al. (1976) suggested a correlation for the entrainment coefficient $E$ in terms of the auperficial gas velocity and the diameter of the largant drop which can he carried upward by the gas flow. Katnoks and lshii (1984) used a momenium balance to relate this drop sizc to the superficial gas velocity and oxpressed the Rozen et al. correlation in the form

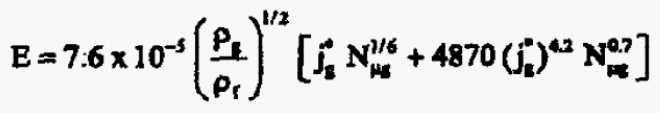

where $j_{b}^{*}$ is a dimensionless superficial gas velocity defined as

$$
j_{s}=j_{11}\left(\frac{p_{t}^{2}}{\sigma g p_{l}}\right)^{1 / 4}
$$

and $\mathbf{N}_{\mathbf{w}}$ is a dimensionless gas viscosity defined by

$$
\mathbf{N}_{w w}=\mu_{v}\left(\frac{g \rho_{c}}{\rho_{u}^{2} \sigma^{3}}\right)^{1 / 4}
$$




\section{RPP-9689 REV 4}

2-7

In the abova definitions $H_{3}$ and $p_{8}$ are, respectively, the gas viscosity and density.

Kataoka and Ishii (1984) devcloped their own cotrelation of acrosol production in the chum turbulent regime, which is

$$
B=7.13 \times 10^{-1}\left(j_{8}^{0}\right)^{3} N_{N *}^{1 / 2}
$$

The numcrical coefficient was ohtained by a best fit of Eq.(7) to the steam-water data of Garner ul. (1954): for $0.5<j_{3}<1.3 \mathrm{~m} \mathrm{~s}^{-1}$ and the alt-water data of Golub (1970) for $0.5<j_{3}<2.0 \mathrm{~m}$ $s^{-1}$. Note that Gamer ef al. reported entrainment data taken in both the bubblo and chum turbulent regimes.

\subsection{Entrilnment Coefiolent for Stan-Whter Svatem}

The relevant physical properties for a boiling pool of water at $0.1 \mathrm{MPa}$ are $\sigma=0.059 \mathrm{~kg} \mathrm{~s}^{-}$ ${ }^{2}, p_{f}=960 \mathrm{~kg} \mathrm{~m}^{-3}, p_{8}=0.6 \mathrm{~kg} \mathrm{~m}^{-3}$, and $\mu_{8}=1.2 \times 10^{-5} \mathrm{~kg} \mathrm{~m}^{-1} \mathrm{~s}^{-1}$. Subatituting these property values into the dofinitions given by Bqs. (2-11) and (2-12) yiclds the relations

$$
\begin{aligned}
& j_{z}=0.16 j_{v} \\
& N_{\mu_{3}}=12.7 \times 10^{-3}
\end{aligned}
$$

where $j_{4}$ is in units of $\mathrm{m} \mathrm{s}^{-1}$. Combining Bgs. (2-10), (2-14), and (2-15) yields the following dimensional form of the Rozen et al, (1976) correlation for the steam-water aystem:

$$
E=10^{-7} j_{1}+3.93 \times 10^{-4} j_{i}^{42} \quad \text { (Rosen et al.) }
$$

From Equ. (2-13) to (2-15), the Kataoka and Ishii (1984) correlation for the steam-water system becomes 
RPP-9689 REV 4

In Eqs. (2-16) and (2-17) $\mathrm{j}_{z}$ is in units of $\mathrm{m} \mathrm{s}^{-1}$. Recall that for superfioial steam volocitics less than $j_{\text {Ee }}$ the iwo-phase pool behavior is in the bubbly flow regime. For the steam-water system $j_{c s}=0.047 \mathrm{~m} \mathrm{~s}^{-1}$.

Tho entrainment coefficient for the bubbly flow regime and Eqs. (2-16) and (2-17) for the churn-hurbulent flow regime are plotted in Fig. 2-I. The bubble burst date of Camer et al. (1954) and Tomaidos and Whitby (1976) are indicated in the figure. Also the stearn-water data reportcd by Gamer et al. for the chum lurbulent regime are presented in the figure. The semi-empirical correlations as well as the data wuggest that the cntrainmont cocficiant undergoes a dranatic reduction upon transition from the bubbly flow regine to the chum turbulent flow regime. Ginsberg (1983) constructed a plot similar to tho one in Fig. 2-1 and first noted this behavior. He speculated that the $\mathrm{E}$ veross $j_{n}$ trend exhibited in the figure is a result of bubble conlescence and reduction of liquid-vapor interfacial surface area with change in flow regime. An alternative explanation is that in the low gas fhux regime (bubbly flow) the entrainment is small but the cntrained liquid consists of very fine drops which are all carried away by the gas flow. In the chum turbulent regine a considerable amount of liquid is entrained but larger drops are ejected from the pool and most of these entrained drops fall back to the surface.

The Rosen of al. (1976) and Kataoka and Ishii (1984) correlations give similar results for $E$ in the range of $j_{g}$ values for which there is data. Unfortumately, as the bubbly flow regime is approseched by decreasing $j_{g}$ the two correlations diverge, and there is no data to provide support for one correlation relative to the other. Obviously the safe (conservative) choice in this region is the correlation of Rozen et al. (1976).

\subsection{Exomole Probloms}

We shall ilhustrate the results roviewed in the foregoing by two examples, first refening to a process tank with a volumetric self heat rate of $Q^{-1}=100 \mathrm{~W} \mathrm{~m}^{-3}$ in sludge with water-like 


\section{RPP-9689 REV 4}

interstitial liquid. Assuming that all the power generted is converted to water vapor, the suporficial vapor velocity at the pool surface is given by the equation

$$
j_{z}=\frac{\phi^{*} H}{P_{z} b_{k}}
$$

where $\mathrm{H}$ is the depth of the liquid and $\mathrm{b}_{\mathrm{f}}$ is the latent heat of cvaporation of water $\left(2.3 \times 10^{6} \mathrm{~J}\right.$ $\mathrm{kg}^{-1}$ ). Taking a liquid depth $\mathrm{H}-3,0 \mathrm{~m}$ we get from Bq. (2-18) $\mathrm{j}_{\mathrm{g}}=2 \times 10^{-4} \mathrm{~m} \mathrm{~s}^{-1}$. This low superficial yapor velocity elearly lies in the bubbly flow regime (see Fig. 2-1) and the appropriate (best estimate) entrainment cosfficient for the rather impure waste liquid is $E-2 \times$ $10^{-7}$. Consequently, the actosol superficial velocity at any height above the pool is $\mathrm{j}_{\mathrm{f}}-\mathrm{Ej}_{8}=4 \mathrm{x}$ $10^{\prime 11} \mathrm{~m} \mathrm{~s}^{-1}$. The total aerosol production rate tn $\mathrm{kg} \mathrm{s}^{-1}$ is obtained by simply multiplying $\mathrm{j} f$ by the product paA where " $A$ " is the cross-sectional area of the process tank

Since the self-heat rate $\dot{Q}^{\prime \prime}=100 \mathrm{~W} \mathrm{~m}^{-3}$ probably represents an upper bound value for the process tanks, it is reasonable to infer from the previous example that the cnerainment coefficient for bubbly flow (E $-2 \times 10^{-7}$ ) should be used for prediction of the worosol goneration rate above a process liquid (sludge) pool undergoing steady-state boiling. The chum turbulent flow regime may materialize during transient events involving the sudden release of gas and/or vapor from the waste material (e.g., during s steam bump).

As a Becond examplo, wo consider aerosols generated by air sparging of liquid waste (pneumercator llow). The aerosol production rate $Q_{n}$ (in $\mathrm{m}^{\text {' s }} \mathrm{s}^{-\mathrm{t}}$ ) may be written as

$$
Q_{1}-\mathbf{E} Q_{2}
$$

where $Q_{g}$ is the gas volumetric flow ratc. If the pneumercator flow is $Q_{k}=0.068 \mathrm{~m}^{3} \mathrm{hr}^{-1}$, the aerosol generation rate using E $=2 \times 10^{-7}$ for very impure liquids is $Q_{4}=1.4 \times 10^{-4} \mathrm{~m}^{3} \mathrm{hr}^{-1}$. 
RPP-9689 REV 4

2-10

\subsection{Conclading Remarks}

With respect to boiling waste, aerosol generation in addition to that produced by bubble burat may occur via condensation of the flowing vapor (i.e., fog formation) as it mixes with cool air some distance above the surface of the pool. Future work should be devoted to this issue.

In cloking this soction, the nood for droplot production data obtained with bubble burat experiments in near-prototypic waste liquids is re-emphasized. The high concentrations of dissolved and suspended materials suggest very low entrainment coefficients for liquid wasto. 
RPP-9689 REV 4

This page intentionally left blank.

B-12 
RPP-9689 REV 4

\section{APPENDIX C}

\section{PEER REVIEW CHECKLIST}

C-i 
RPP-9689 REV 4

This page intentionally left blank.

C-ii 


\section{APPENDIX C}

\section{PEER REVIEW CHECKLIST}

\section{CHECKLIST FOR TECHNICAL PEER REVIEW}

Page 1 of 2

Document Reviewed: ECN 723851 R0 (RPP-9689, Offsite Radiological Consequence Calculation for the Bounding Mixing of Incompatible Materials Accident, Revision 4)

Scope of Review (e.g., document section or portion of calculation): Changes from Revision 3 to Revision 4.

\section{Yes No* NA}

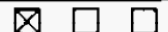

$\bigotimes \square \square$

$\bigotimes$

区

区

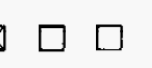

$\square \square \square$

$凶$

$凶$

1. Previous reviews are complete and cover the analysis, up to the scope of this review, with no gaps. *Explanation:

2. Problem is completely defined. *Explanation:

3. Accident scenarios are developed in a clear and logical manner. *Explanation:

4. Analytical and technical approaches and results are reasonable and appropriate. (ORP QAPP criterion 2.8) 'Explanation:

5. Necessary assumptions are reasonable, explicitly stated, and supported. (ORP QAPP criterion 2.2) *Explanation:

6. Computer codes and data files are documented.

Explanation: No compuser codes were used

7. Data used in calculations are explicitly stated *Explanation:

8. Bases for calculations, including assumptions and data, are consistent with the supported safety basis document (e.g., the Tank Farms Documented Safety Analysis). "Explanation:

9. Data were checked for consistency with original source information as applicable. (ORP QAPP criterion 2.9) 'Explanation:

10. For both qualitative and quantitative data, uncertainties are recognized and discussed, as appropriate. (ORP QAPP criterion 2.17) *Explanation:

11. Mathematical derivations were checked including dimensional consistency of results. (ORP QAPP criterion 2.16) "Explamation:

12. Models are appropriate and were used within their established range of validity or adequate justification was provided for use outside their established range of validity. 'Explanation: No models were used.

13. Spreadsheet results and all hand calculations were verified. -Explenotion:

14. Calculations are sufficiently detailed such that a technically qualified person can understand the analysis without requiring outside information. (ORP QAPP criterion 2.5) Explanation:

15. Software input is correct and consistent with the document reviewed. *Explanation: No software was used

16. Software output is consistent with the input and with the results reported in the document reviewed. "Explanation: No software was used.

17. Software verification and validation are addressed adequately. (ORP QAPP criterion 2.6) Explanation: No software was used.

$\otimes \square \square$ 18. Limits/criteria/guidelines applied to the analysis results are appropriate and referenced. Limits/criteria/guidelines were checked against references. (ORP $Q A P P$ criterion 2.9) "Explanatton:

$\otimes \square \square \quad$ 19. Safety margins are consistent with good engineering practices.

Explanation:

$\bigotimes \square \square \quad 20$. Conclusions are consistent with analytical results and applicable limits. "Explanation: 


\section{RPP-9689 REV 4}

\section{CHECKLIST FOR TECHNICAL PEER REVIEW}

21. Results and conclusions address all points in the purpose. (ORP QAPP criterion 2.3) *Explanation:

22. All references cited in the text, figures, and tables are contained in the reference list. *Explanation:

23. Reference citations (e.g., title and number) are consistent between the text callout and the reference list.

*Explanation:

24. Only released (i.e., not draft) references are cited. (ORP QAPP criterion 2.1) Expianation:

25. Referenced documents are retrievable or otherwise available. "Explanation:

26. The most recent version of each reference is cited, as appropriate. (ORP QAPP criterion 2.1) Explanation:

27. There are no duplicate citations in the reference list. Explanation:

28. Referenced documents are spelled out (title and number) the first time they are cited. *Explanotion:

29. All acronyms are spelled out the first time they are used. Explanation:

30. The Table of Contents is correct. "Explanation:

31. All figure, table, and section callouts are correct. *Explanation:

32. Unit conversions are correct and consistent. *Explanation:

33. The number of significant digits is appropriate and consistent. Explanation:

34. Chemical reactions are correct and balanced. ${ }^{\star}$ Explanation: No chemical reactions were used.

35. All tables are formatted consistently and are free of blank cells. *Explanation: No changes to rables were made.

36. The document is complete (pages, attachments, and appendices) and in the proper order. "Explanation:

37. The document is free of typographical errors. Only the section(s) being reviewed was checked for typographical errors. "Explanation:

38. The tables are internally consistent. *Explanation:

39. The document was prepared in accordance with HNF-2353, Section 4.3, Attachment B, "Calculation Note Format and Preparation Instructions." "Explanation: This was a change to an existing document and was not a change to a calculation note.

40. Impacted documents are appropriately identified in Blocks 7 and 24 of the Engineering Change Notice (form A-6003-563.1). *Explanation:

$\otimes \square \square \quad 41$. If more than one Technical Peer Reviewer was designated for this document, an overall review of the entire document was performed after resolution of all Technical Peer Review comments and confirmed that the document is selfconsistent and complete. Explanation:

\section{$\otimes \square \square$ Concurrence}

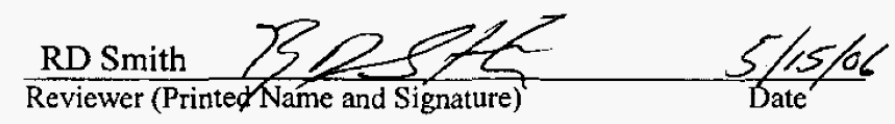

* If No or NA is chosen, an explanation must be provided on this form.

Additional explanation: 


\section{CHECKIIST FOR TECHNICAL PEER REVIEW}

Document Reviewed: RPP-9689, Offsite Radiological Consequence Calculation for the Bounding Mixing of Incompatible Materials Accident, Rev. 4

Scope of Review (e.g., document section or portion of calculation): Technical edit

Yes No $\mathrm{NA}^{*}$

[] [ ] [x] 1. Previous reviews are complete and cover the analysis, up to the scope of this review, with no gaps.

I] [ ] [x] 2. Problem is completely defined.

[] [] [x] 3. Accident scenarios are developed in a clear and logical manner.

[] [] [x] 4. Analytical and technical approaches and results are reasonable and appropriate. (ORP QAPP criterion 2.8)

[ ] [ ] [x] 5. Necessary assumptions are reasonable, explicitly stated, and supported. (ORP QAPP criterion 2.2)

[ ] [ ] [x] 6. Computer codes and data files are documented.

[] [] [x] 7. Data used in calculations are explicitly stated.

[] [] [x] 8. Bases for calculations, including assumptions and data, are consistent with the supported safety basis document (e.g., the Tank Farms Final Safety Analysis Report).

[ ] [ ] [x] 9. Data were checked for consistency with original source information as applicable. (ORP QAPP criterion 2.9)

[ ] [ ] [x] 10. For both qualitative and quantitative data, uncertainties are recognized and discussed, as appropriate. (ORP QAPP criterion 2.17)

[] [ ] [x] 11. Mathematical derivations were checked including dimensional consistency of results. (ORP QAPP criterion 2.16)

[ ] [ ] [x] 12. Models are appropriate and were used within their established range of validity or adequate justification was provided for use outside their established range of validity.

[ ] [] [x] 13. Spreadsheet results and all hand calculations were verified.

[] [ ] [x] 14. Calculations are sufficiently detailed such that a technically qualified person can understand the analysis without requiring outside information. (ORP QAPP criterion 2.5)

[] [] [x] 15. Software input is correct and consistent with the document reviewed.

[] [] [x] 16. Software output is consistent with the input and with the results reported in the document reviewed.

[ ] [ ] [x] 17. Software verification and validation are addressed adequately. (ORP QAPP criterion 2.6)

[] [] [x] 18. Limits/criteria/guidelines applied to the analysis results are appropriate and referenced. Limits/criteria/guidelines were checked against references. (ORP QAPP criterion 2.9)

[] [] [x] 19. Safety margins are consistent with good engineering practices.

[] [] [x] 20. Conclusions are consistent with analytical results and applicable limits.

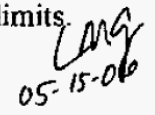




\section{CHECKLIST FOR TECHNICAL PEER REVIEW}

[ ] [ ] [x] 21. Results and conclusions address all points in the purpose. (ORP QAPP criterion 2.3)

[x] [ ] [ ] 22. All references cited in the text, figures, and tables are contained in the reference list.

[x] [ ] [ ] 23. Reference citations (e.g., title and number) are consistent between the text callout and the reference list.

[x] [ ] [ ] 24. Only released (i.e., not draft) references are cited. (ORP QAPP criterion 2.1)

[x] [] [] 25. Referenced documents are retrievable or otherwise available.

[x] [ ] [ ] 26. The most recent version of each reference is cited, as appropriate. (ORP QAPP criterion 2.1)

[x] [ ] [ ] 27. There are no duplicate citations in the reference list.

[x] [] [] 28. Referenced documents are spelled out (title and number) the first time they are cited.

[x] [ ] [ ] 29. All acronyms are spelled out the first time they are used.

[x] [] [] 30. The Table of Contents is correct.

[x] [ ] [] 31. All figure, table, and section callouts are correct.

[x] [ ] [] 32. Unit conversions are correct and consistent.

[x] [] [ ] 33. The number of significant digits is appropriate and consistent.

[ ] [ ] [x] 34. Chemical reactions are correct and balanced.

[x] [] [] 35. All tables are formatted consistently and are free of blank cells.

[x] [] [ ] 36. The document is complete (pages, attachments, and appendices) and in the proper order.

[x] [ ] [ ] 37. The document is free of typographical errors.

[x] [ ] [] 38. The tables are internally consistent.

[x] [] [] 39. The document was prepared in accordance with HNF-2353, Section 4.3, Attachment B, "Calculation Note Format and Preparation Instructions".

[ ] [ ] [x] 40. Impacted documents are appropriately identified in Blocks 7 and 24 of the Engineering Change Notice (form A-6003-563.1).

[x] [] [] 41. If more than one Technical Peer Reviewer was designated for this document, an overall review of the entire document was performed after resolution of all Technical Peer Review comments and confirmed that the document is selfconsistent and complete.

\section{[x] [] [I Concurrence}

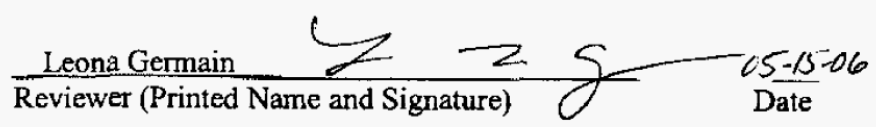

* If No or NA is chosen, provide an explanation on this form.

Technical Edit 